\title{
19. SZÁZADI ÉPÜLETEK ÉRTÉKVÉDELME GYÖR-MOSON-SOPRON MEGYÉBEN
}

\author{
VEÖREÖS ANDRÁS \\ PhD, okleveles építészmérnök, müemléki szakügyintézö. \\ Győr-Moson-Sopron Megyei Kormányhivatal Győri Járási Hivatal Építésügyi és Örökségvédelmi Osztály, \\ 9400 Sopron, Kolostor utca 13. E-mail: andras.veoreos@gmail.com
}

\begin{abstract}
A 19. századi védett épületek aránya nagy valószínüséggel elmarad a teljes történeti épületállományon belül az ebből az időszakból származó épületek arányától. Elgondolkodtató ez amiatt, hogy a müemléki védelmet nem élvező klasszicista és romantikus, de még inkább a századvégi historizáló és szecessziós építészeti emlékeink jelentős része rendelkezik az eredeti (védhető/védendő) épületalkatrészekkel. Ezzel szemben a szinte kivétel nélkül védettség alatt álló középkori vagy barokk kori épületeinken a fö tartószerkezet kivételével alig találunk eredeti, építéskori épületalkatrészeket. Így tetőszerkezetek, tetőfedések, padlásszellőzők, padló- és falburkolatok, ajtók, ablakok, kapuk, kilincsek, rácsok, lépcsőkorlátok, vakolatok, díszítőfestés, stukkó, cserépkályhák nyújtanak képet a korszak építési technikájának rendkívül magas színvonaláról. A müemléki értékek pusztulása alapvetően három okra vezethető vissza: müszaki, erkölcsi és bürokratikus avulásra. Az elavult szerkezetek esetében válik szükségessé a valamilyen szintü felújítás, ami sok esetben szintén az eredeti épületelemek károsodásához vezet. Jelen cikk néhány jellemző példa bemutatásával próbál meg képet adni a 19. századi, müemléki értékkel bíró épületek megőrzése körüli dilemmákról.
\end{abstract}

Kulcsszavak: historizmus, müemlékvédelem, eredeti épületalkatrészek

\section{19. SZÁZADI MÜEMLÉKEK ARÁNYA}

Jelen cikk az MTA Építészettörténeti, Építészetelméleti és Műemléki Állandó Bizottságának 2018. április 23-án, a Budapesti Müszaki és Gazdaságtudományi Egyetemen Istvánfi Gyula nyolcvanadik és Kalmár Miklós hetvenedik születésnapja alkalmából megrendezett Ünnepi ülésen elhangzott előadás összefoglalása. A témaválasztás részben a bizottság alapvető müködési területeihez (építészettörténet és müemlékvédelem), részben pedig az ünnepeltek kutatási területeihez (19. századi építészet és népi építészet) kapcsolódik.

Első lépésként szükségesnek látszik a címben szereplő 19. századi építészet definíciója. Az általános szakirodalomhoz igazodva, Kalmár Miklós és Winkler Gábor időhatárainak megfelelően a 18. század végének klasszicizáló késő barokk (copf) emlékeivel kezdődő korszak vége az első világháború, de tágabb értelemben idesorolhatók a két világháború közötti historizáló építészet emlékei is, bár utóbbiak között aligha találunk jogi értelemben a védelem bármely szintjén álló épületet. 
A rangos építészet emlékei mellett építési idejük szerint ide kell sorolnunk a népi építészet fennmaradt emlékeit is, hiszen ezek legnagyobb része szintén a tárgyalt korszakban keletkezett, csupán elvétve találunk 18. századi falusi épületet.

A müemlékállomány tekintetében Győr-Moson-Sopron megyében végeztünk áttekintést annak megállapítására, hogy a védelem alatt álló épületek hány százaléka tartozik a tárgyalt korszak emlékei közé. A müemlékjegyzékben klasszicista, romantikus, eklektikus vagy szecessziós stílusúként megjelölt épületek aránya a megye nagyobb városaiban az alábbiak szerint alakul: ${ }^{1}$

\begin{tabular}{|l|c|c|c|}
\hline \multicolumn{1}{|c|}{ Település } & Mủemlékek száma & $\begin{array}{c}\text { 19. századi mủemlékek } \\
\text { száma }\end{array}$ & Százalékos eloszlás, \% \\
\hline Sopron & 450 & 110 & 25 \\
\hline Győr & 250 & 109 & 40 \\
\hline Mosonmagyaróvár & 65 & 27 & 35 \\
\hline Csorna & 7 & 1 & 14 \\
\hline Kapuvár & 3 & 1 & 33 \\
\hline
\end{tabular}

Az öt településen található védett épületek a megye műemlékállományának mintegy felét teszik ki. A vizsgálatot kiegészítve a vidék müemlékeivel azt tapasztaljuk, hogy - bár nagyszámú népi lakóházat is találunk a jegyzékben - a védett épületek többsége középkori vagy barokk falusi templom, és jelentős a száma a védett út menti szobroknak is. Összességében a védett objektumoknak körülbelül egyharmadát teszik ki a 19. századi emlékek.

Megvizsgálandó azonban, hogy a teljes történeti épületállományon (második világháború előtt épült épületek) belül mekkora a 19. századi épületek aránya. Részletes kutatás nélkül a fentinél jóval magasabb arány valószínüsíthető. A tárgyalt korszak emlékeinek magas aránya a védett épületek között nagy valószínüséggel a Győrött és Sopronban aktívan tevékenykedő, a korszakot jól ismerö, feltehetőleg számos védési javaslattal előálló Winkler Gábor közremüködésének is köszönhető.

\section{MÜEMLÉKEK EREDETI ALKATRÉSZEI}

A müemlékvédelem alapvető, sokszor feltett kérdése, hogy mit védünk az adott épületen? A legújabb szabályozások már elöírják a müemléki értékleltár elkészítésének kötelezettségét, és vizsgálni kell a tervezett beavatkozások ezekre gyakorolt hatásait is. A müemléki értékek esetében a megőrzésre, a felújításra kell törekedni. ${ }^{2}$

\footnotetext{
${ }^{1}$ Magyarország müemlékjegyzéke. Hozzáférés a Győr-Moson-Sopron Megyei Kormányhivatal Győri Járási Hivatal Építésügyi és Örökségvédelmi Osztályának online adatbázisán keresztül.

${ }^{2} \mathrm{~A}$ müemléki értékleltár elkészítésének kötelezettségét és a szükséges adattartalmat a kulturális örökség védelmével kapcsolatos szabályokról szóló 68/2018. (IV.9.) Korm. rendelet írja elő.
} 
Hazánk müemlékállományában - a néhány rendkívül töredékesen fennmaradt római emléken túl - a legrégebbi épületek a középkorból származnak. Míg néhány román kori vagy gótikus templomunk kevesebb átalakítással érte meg korunkat, a középkori várak többsége már csak rom formájában maradt fenn. A korszak lakóépületei is csupán átépítve állnak, még gyakoribb, hogy egy-egy épületrészletük későbbi épületbe belefoglalva látható.

A középkorból származó épületek materiálisan megfogható, „eredeti” elemei többnyire csupán a falak, boltozatok, kőkeretek és egyéb faragott kő alkatrészek, néhány esetben a falképek, melyekhez értelemszerüen korabeli vakolatok is tartoznak. Elenyésző azonban az ebből a korból származó fedélszerkezetek, nyílászárók, padlóburkolatok száma. A középkori épületek múemléki értékei közé tartozik természetesen a térszerkezet, amennyiben azt nem alakították át az évszázadok során.

Fentiekből látható, hogy a koruknál fogva értelemszerüen nagy becsben tartott, szinte kivétel nélkül müemléki védelemben részesülő középkori épületek között aligalig találunk olyan épületelemet, mely valóban középkori.

A török hódoltságot követő időszakból származó épületeink már barokk stílusban épültek. Mivel korban hozzánk jóval közelebbi korszakról van szó, értelemszerüen nagyobb az ebből az időszakból származó épületeink száma, és jóval nagyobb az eredetinek tekinthető épületalkatrészek aránya is. Számos barokk kori fedélszerkezetet, kő- vagy fapadlót ismerünk, de szép számmal maradtak fenn nyílászárók is, elsősorban belső ajtók formájában. Ennek ellenére azt a megállapítást kell tennünk, hogy a barokk kori védett épületeink látható épületelemei - függetlenül attól, hogy az épület felújításra szorul vagy helyreállított állapotban van-e - többségükben szintén nem eredetiek, azokat az idők során kicserélték, eredetinek többnyire itt is csupán a falak, a födémek, a boltozatok és néhány esetben a kiegészítő szerkezetek tekinthetök.

A Kárpát-medencei történeti építészet harmadik korszaka a bevezetőben ismertetett 19. század. A korszakból fennmaradt épített örökség rendkívül sok épületből áll, ami egyrészt az időben közelebbi keletkezésnek, másrészt a fiatalabb és emiatt jobb müszaki állapotú épületállománynak, harmadrészt pedig a korszak csodálatra méltó teljesítményre képes, rendkívül nagy arányú építőtevékenységének köszönhető. Hazánkban a kiegyezés és az első világháború között épült ki a teljes vasúthálózat a hozzá tartozó épületállománnyal, ekkor épült fel Pest és a többi nagyváros központja, ipari épületek sokasága, a közigazgatási, közmüvelődési és oktatási épületek jelentős része, valamint a ma még álló történeti falusi lakó- és gazdasági épületeink.

A 19. századi épületek nagy számának, valamint az épületek kiváló műszaki minőségben való megalkotásának köszönhetően ezeknek az épületeknek a jelentős része rendelkezik építés korabeli alkatrészekkel: a fö tartószerkezeteken kívül tetőszerkezetek, tetőfedések, padlásszellőzők, padló- és falburkolatok, ajtók, ablakok, kapuk, kilincsek, rácsok, lépcsőkorlátok, vakolatok, díszítőfestés, stukkó, cserépkályhák sokasága tanúskodik a historizáló vagy éppen a századvég szecessziós stílusú építötevékenységének gazdagságáról. A teljes 19. századi épületállományra vetítve nagy valószínüséggel csupán az eredeti alkatrészek töredéke található védett épületekben, 
ezen építészeti értékek többsége nem élvez semmiféle védettséget, ami a korunkat jellemző fogyasztói társadalom építőtevékenysége révén azt jelenti, hogy ezek az épületalkatrészek fokozottan ki vannak téve az elpusztítás veszélyének.

\section{A MÜEMLÉKI ÉRTÉKEK PUSZTULÁSÁNAK OKAI}

A müemléki értékek pusztulása alapvetően három okra vezethető vissza: ${ }^{3}$

\subsection{MÜSZAKI AVULÁS}

Az építőanyagok, épületszerkezetek élettartama véges. Az őket érő fizikai, kémiai és biológiai hatások függvényében bizonyos anyagok gyorsabban, mások lassabban öregszenek. Vannak szerkezetek, melyek öregedése szép, patinás megjelenést kölcsönöz az épületnek, más szerkezetek öregedése kifejezetten csúnya.

A müemlékvédelem - ebből a szempontból nézve tulajdonképpen észszerütlen törekvése az anyagok, szerkezetek élettartamának a meghosszabbítása. A folyamatos karbantartással, az apró hibák rendszeres javításával az egész épületet tekintve természetesen jelentős élettartam-hosszabbodás érhető el.

A műszaki avulás tragikus formája a természeti katasztrófák (árvíz, földrengés, tüz) következtében jelentkező tönkremenetel, de ide tartozik a tudatos rombolás, illetve szélsőséges esetben az épület(rész) elbontása is.

\subsection{ERKÖLCSI AVULÁS}

Erkölcsi avulásnak nevezzük, amikor egy épület vagy épületszerkezet müszakilag ugyan megfelelö állapotban van, de mégsem tudja a mai kor által támasztott igényeket kielégíteni, emiatt válik szükségessé az épületen a beavatkozás, aminek szükségszerü következménye a meglevő, akár müemléki értékkel bíró szerkezetek sérülése, pusztulása.

Legjellemzőbb esetek az épület alaprajzának átrendezéséhez, belső tereinek átalakításához vagy a hőszigetelő-képesség javításához kapcsolódó szerkezetmegújítások, melyek során a történeti épületrész értékek károsodásával járó korszerüsítésére vagy éppenséggel elbontására kerül sor.

\subsection{BÜROKRATIKUS AVULÁS}

Ebbe a csoportba tartoznak azon esetek, amikor a történeti szerkezet mind objektív müszaki állapotát, mind funkcióját tekintve megfelel, azonban a jóval az épület

\footnotetext{
${ }^{3}$ Román András a műszaki és az erkölcsi avulás fogalmát használta. Román András: 487 bekezdés és 617 kép a müemlékvédelemről. Terc Kiadó, Budapest 2004.
} 
keletkezése után hozott szabványok új épületekre vonatkozó paramétereit nem tudja kielégíteni. Legtöbbször a tartószerkezeti és a tüzvédelmi elöírások jelentik a régi szerkezet fennmaradásának, megőrzésének akadályát. A jogi szabályozás általában nem, vagy csak nagyon körülményes úton kijárható módon tesz kivételt a múemléki értékủ szerkezetekkel, ilyen módon a tapasztalati úton igazolható paraméterek (az épület az esetleg több száz éves fennállása során bizonyította, hogy megfelel az öt érő hatásoknak) sem bizonyulnak elegendőnek.

Az épületek pusztulásának okai természetesen összefüggnek. Az okok kialakulásának megelőzése a bürokratikus avulás esetében a legolcsóbb, ezzel szemben a müszaki állapot fenntartása, a folyamatos karbantartás nagyobb anyagi ráfordítást is igényel a tulajdonostól. Mindenképpen meg kell azonban jegyezni, hogy a rendszeres karbantartás esetén az épületre fordított pénz nagyságrendje mesze elmarad a tönkrement, teljes felújításra szoruló épület felújítása, épületrészek rekonstrukciója esetén szükséges anyagi erőforrás mértékétől.

A müemlékvédelmi tevékenységet a társadalomban az identitás keresése és megtalálása, a múltra való emlékezés igénye legitimizálja. A mindenkori cél a meglevő értékek megőrzése, műszaki felújítása (restaurálása), illetve amennyiben elpusztult értékről beszélünk, annak a - lehetőleg hiteles források alapján történő - helyreállítása, visszaállítása (rekonstrukciója). A gyakran használt „eredeti állapotba” való visszaállítás a legtöbb műemlék esetében nem értelmezhető, hiszen egy román kori alapokon álló, gótikus stílusban átépített, majd a török hódoltság után barokk formában megújított, 19. században kibővített épületnek nincsen egyértelmüen meghatározható, eredeti állapota.

A 19. századi épületek ebből a szempontból is különleges helyet foglalnak el a müemlékek között. Egyrészt rövidebb életük alatt ezek az emlékeink kevesebb átépítésen estek át, sokkal több mindent őriztek meg in situ az építéskori (= eredeti) formájukból, anyagaikból és szerkezeteikből, másrészt az épülettől független források (tervrajzok, fényképek) is nagyobb mennyiségben állnak rendelkezésre és dokumentálják az „eredeti” állapotot, lehetővé téve ezzel a hiteles helyreállítást. ${ }^{4}$

\section{A XIX. SZÁZADI ÉPÜLETEK PUSZTULÁSÁNAK FOKOZATAI}

A fent elemzett okok miatt számos értékes 19. századi épület pusztulásának, az értékek elvesztésének lehetünk szemtanúi napról napra. ${ }^{5}$ A pusztulás mértéke változó, az épület teljes eltünésétöl, az átépítésen keresztül az egyes alkatrészek cseréjéig terjed a skála.

\footnotetext{
${ }^{4}$ A műemlékvédelem állandó kérdése a rekonstrukció, a helyreállítás hitelessége. Legutóbb Az ICOMOS Magyar Nemzeti Bizottság az MTA Építészettörténeti, Építészetelméleti és Mủemléki Állandó Bizottsága, valamit az Artifex Kiadó 2016. november 8-án a Magyar Tudományos Akadémián tartott Müemlék, identitás, rekonstrukció címü konferenciája foglalkozott sokoldalúan a kérdéssel.

${ }^{5} \mathrm{Az}$ adatok az elmúlt másfél évtizedben Győr-Moson-Sopron megyében végzett mủemlék-felügyeleti munka során szerzett tapasztalatokon alapulnak.
} 


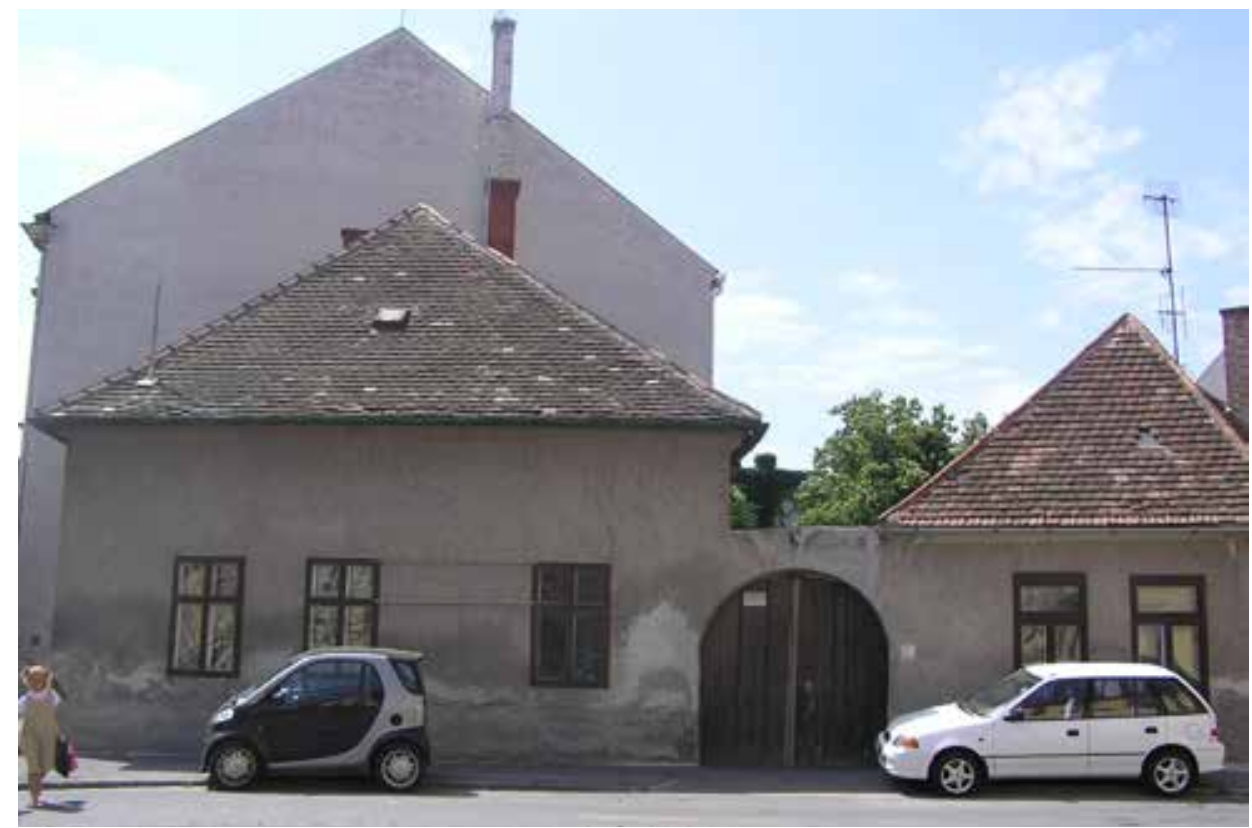

1. ábra. Mára elbontott XIX. századi lakóépület. Sopron, Ógabona tér

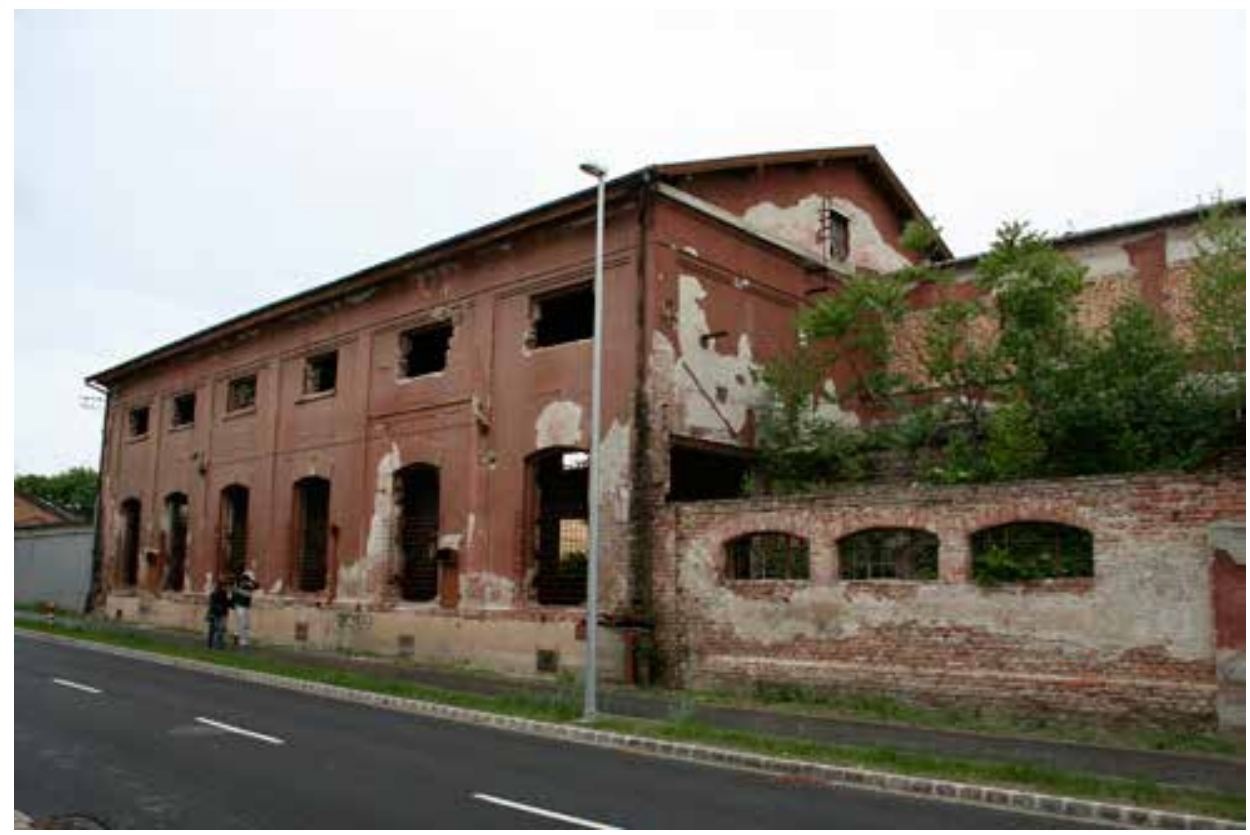

2. ábra. Egykori turbinacsarnok a Flandorffer utcában, Sopronban 


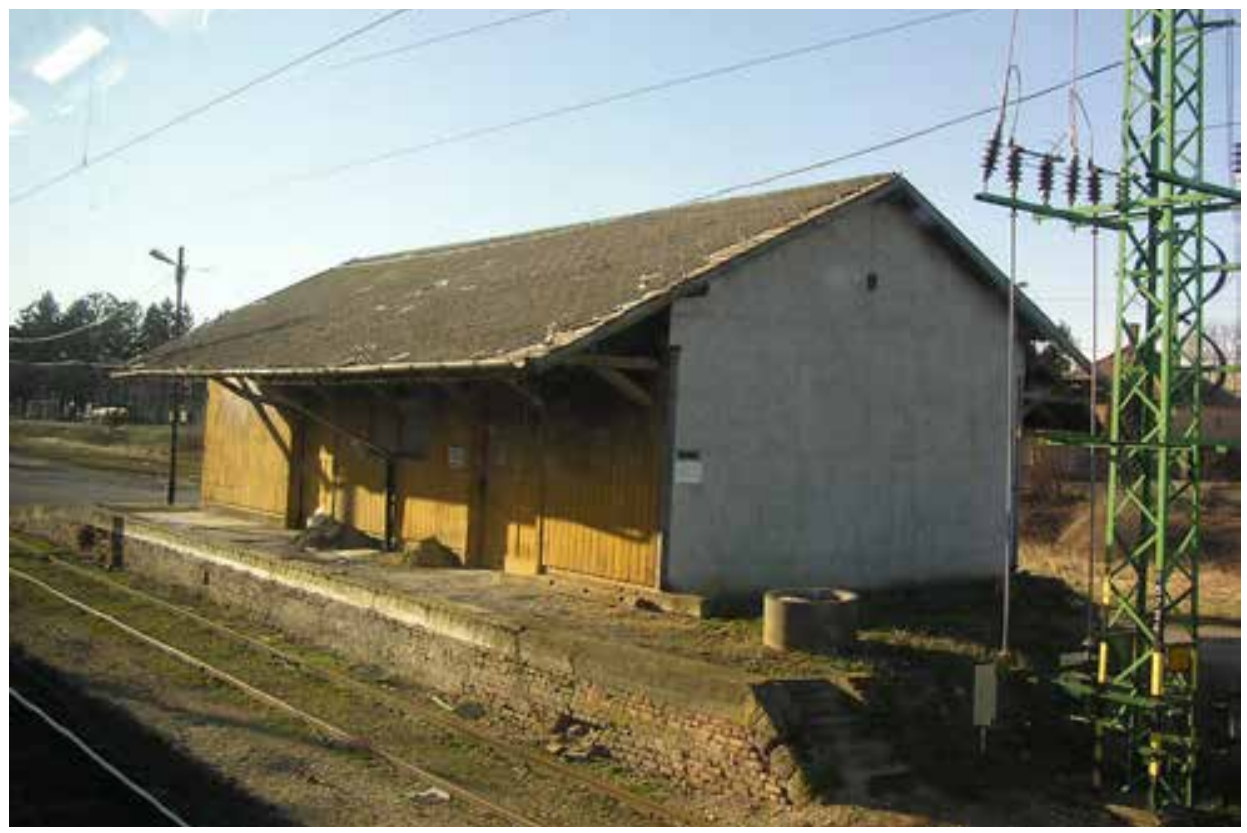

3. ábra. Ma már nem álló vasúti raktár. Lövő

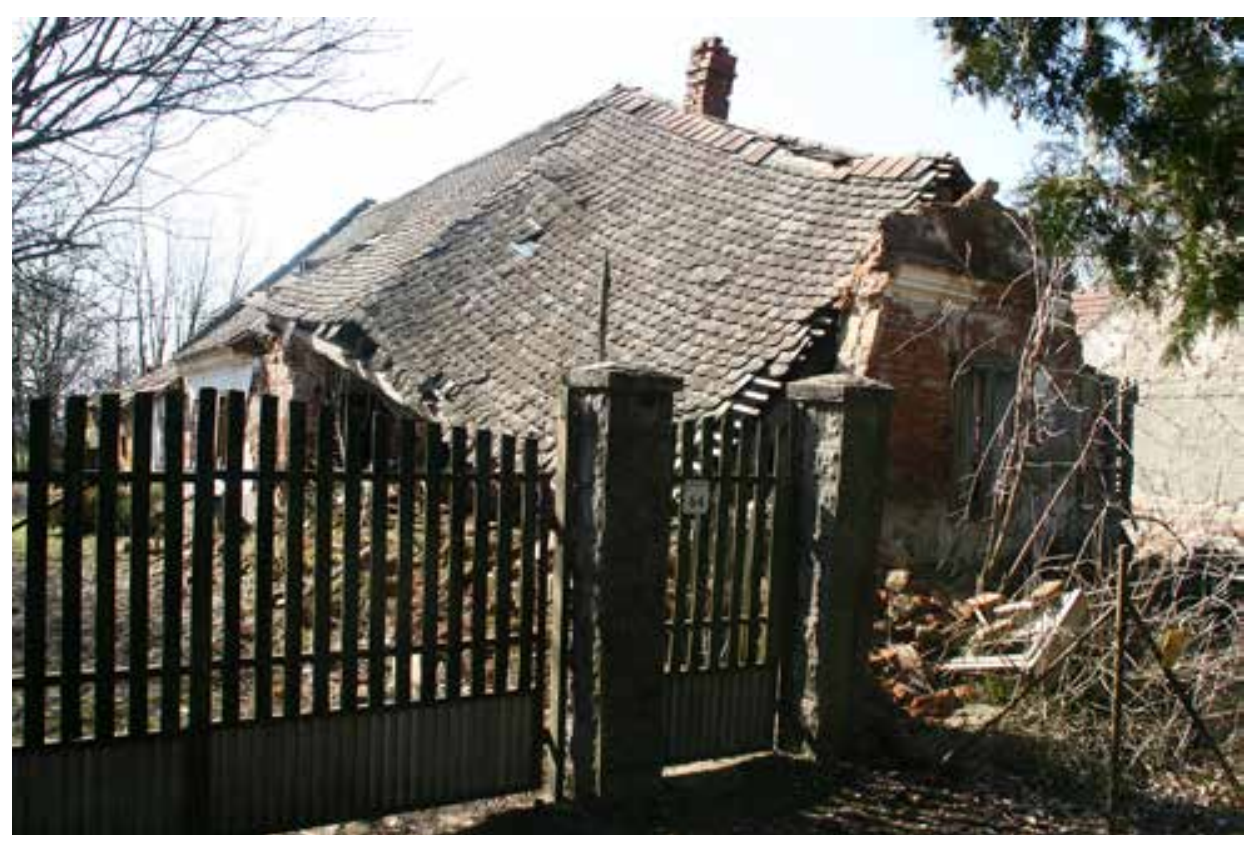

4. ábra. Összedőlt parasztház Zsebeháza faluban 
A teljesen elbontott épületek között találunk lakóépületeket (1. ábra), ipari épületeket (2. ábra) és a hazai történeti épületállomány szempontjából rendkívüli jelentöséggel bíró vasúti épületeket (3. ábra).

A magyar falusi építészet emlékei legnagyobb részt szintén a 19. századi épített örökséghez tartoznak. Elvétve találkozunk csupán ennél régebbi vidéki épületekkel. Pusztulásuk legfőbb oka a társadalom átalakulásában keresendő: Magyarországon gyakorlatilag megszünt az a fajta paraszti életforma, amely ezeket az épületegyütteseket létrehozta (4. ábra).

Szerencsésebb esetben a teljes épület megmenekül a pusztulástól, csupán az egyes alkatrészek végzik a konténerben. A leggyakoribb a történeti értékü nyílászárók és burkolatok kibontása és új szerkezettel való helyettesítése. Az új anyagok és szerkezetek pedig többnyire sem anyagukban, sem részletképzésük tekintetében nem hasonlítanak az eredetiekhez, és sajnos többnyire a minőségük, illetve a tervezett élettartamuk is messze elmarad az eredetiekétől.

Az épületek pusztulásának okai és a tönkremenetel folyamata természetesen független az épület korától, de éppen a 19. századi épületek, illetve az ezekben megmaradt eredeti alkatrészek nagy száma és a védettség hiánya okán ezen épületek körében a legnagyobb az értékvesztés aránya.

A történeti utcaképek megőrzésének egyik lehetséges módozata az, hogy a történeti épületekből csupán a homlokzatot őrzik meg, a mögötte levő épületet pedig teljesen elbontják, és helyére modern épület épül. A faszadizmus természetesen nem

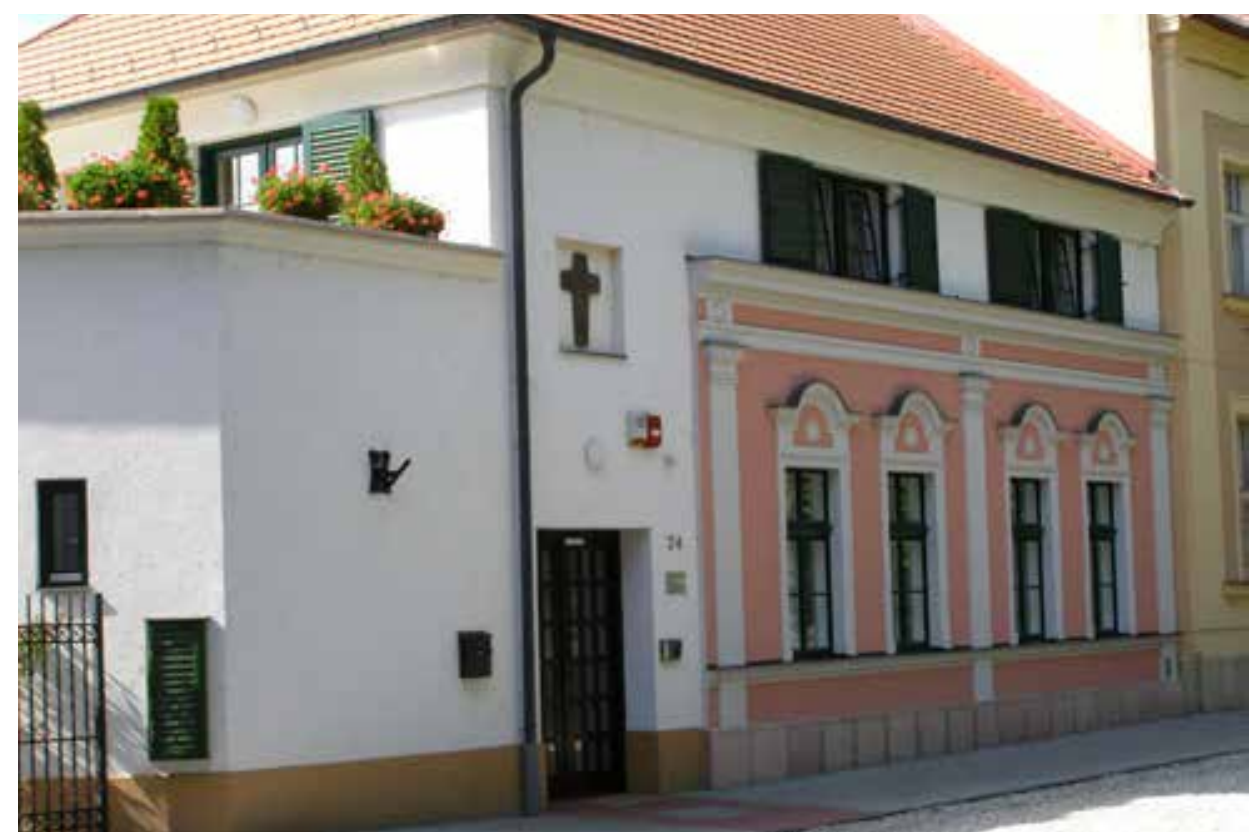

5. ábra. Faszadizmus - historizáló polgárház homlokzata belefoglalva egy új épületbe. Kapuvár 
értelmezhető müemlékek esetében, ahol nem csupán a homlokzat, hanem a belső térrendszer és az épületszerkezetek is védendő értéket képviselnek, ugyanakkor, abban az esetben, ha az épület belsejében nem található (védett) építészeti érték, a homlokzat azonban a településkép szempontjából megörzendő, elfogadható megoldás lehet (5. ábra).

Számos esetben kerül sor az épület részleges vagy teljes átépítésére. Ezekben az esetekben az értékvesztés mértéke a beavatkozás mélységétől függ, szerencsére sokszor csupán az értékek eltakarására, és ezáltal önkéntelen megőrzésére kerül sor. Ebben az esetben a megmaradó értékek egy következő renoválás során felújíthatók, láthatóvá tehetők. A régi épületek átalakítása, korszerüsítése tulajdonképpen egy természetes folyamat, a beavatkozás szereplőinek (építtető, tervező, kivitelező - ha van, hatóság) a felelőssége, hogy az átalakítás során az értékek megőrzése biztosítható-e.

\section{EREDMÉNYEK - MEGÖRIZTÜK?}

A hivatásos müemlékvédelem állandó kudarcélményei közé tartozik, hogy egyegy értékesnek gondolt épületet nem sikerült megvédeni, az épület tönkrement, vagy éppenséggel elbontották, ilyen módon nem gazdagíthatja tovább hazánk építészeti arculatát. Szerencsére vannak azonban olyan esetek is, amikor hatósági vagy egyéb rendelkezésre álló eszközökkel sikerül egy épületet vagy épületrészt a pusztulástól megmenteni. Tekintsük át néhány rövid esettanulmány segítségével, hogyan menekültek meg 19. századi épületek vagy épületrészek Győr-Moson-Sopron megyében az elmúlt években.

\section{Vadosfa, közösségi ház}

Az épület mủemléki környezetben áll, az örökségvédelmi hatósághoz a bontási tervek érkeztek meg. A bontási kérelem elutasítását a szomszédos müemlék látványának megörzésével lehetett alátámasztani. A tulajdonos meggyőzése után először az épület szerkezeti felújítása történt meg, majd az utcai oldalon müanyagra cserélt nyílászáró rekonstrukciója is elkészült. A ház jelenleg a történeti falukép egyik meghatározó eleme (6-7. ábra).

\section{Sarród, lakóház}

A ház az utolsó barokkos oromzatos, tornácos parasztház (volt) a Fertő-part magyarországi oldalán, müszaki állapota nem tette lehetővé optimális keretek közötti felújítását. Hiába állt világörökségi területen, ez önmagában nem biztosított elég védettséget, ezért a felmérési terv készítése során a tervezők nem fektettek hangsúlyt az épület építészeti értékeire, ezek számbavételére csak hosszas - feszültségtől sem 

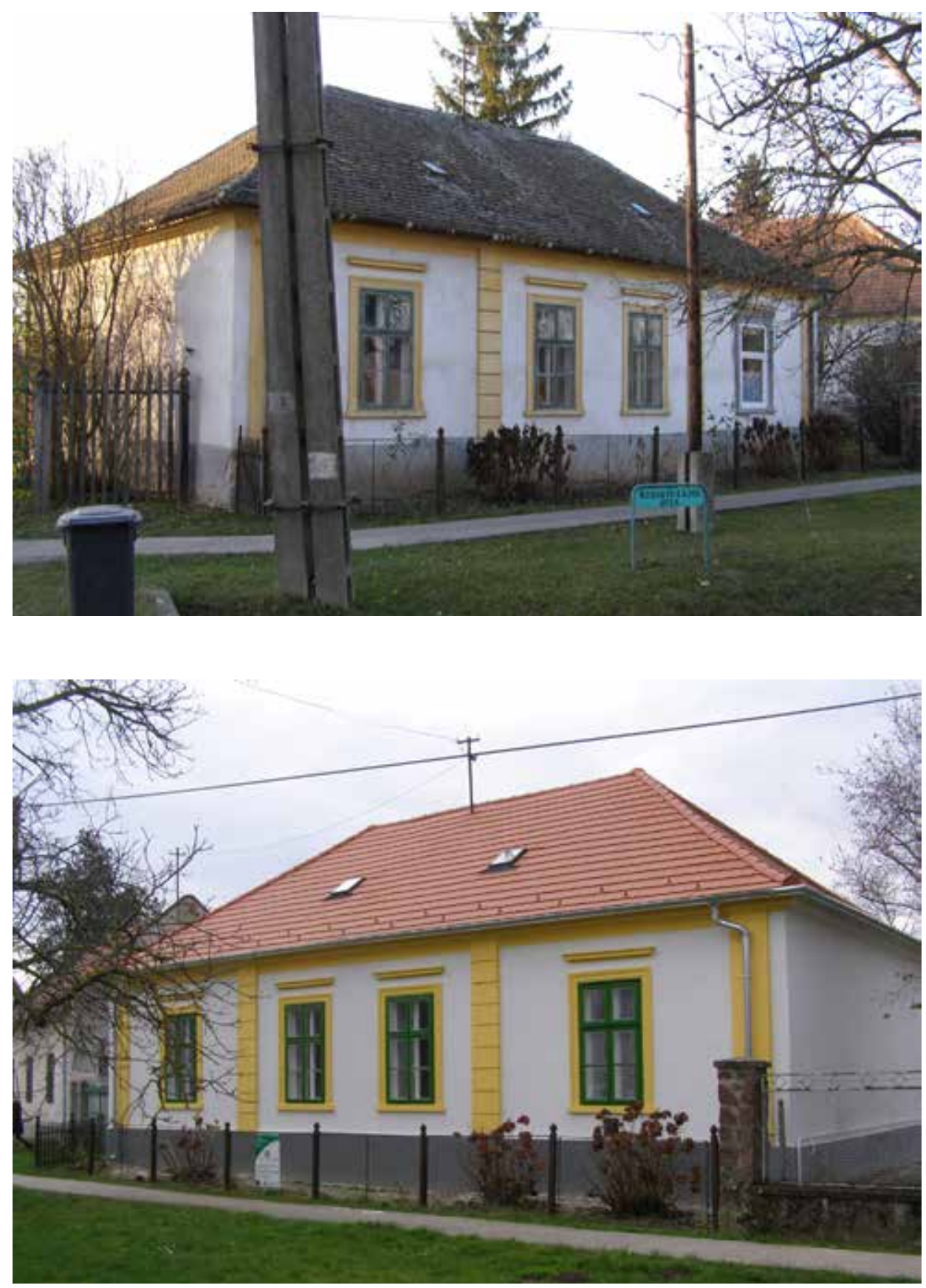

6-7. ábra. Bontásra ítélt, majd felújított közösségi ház Vadosfán 


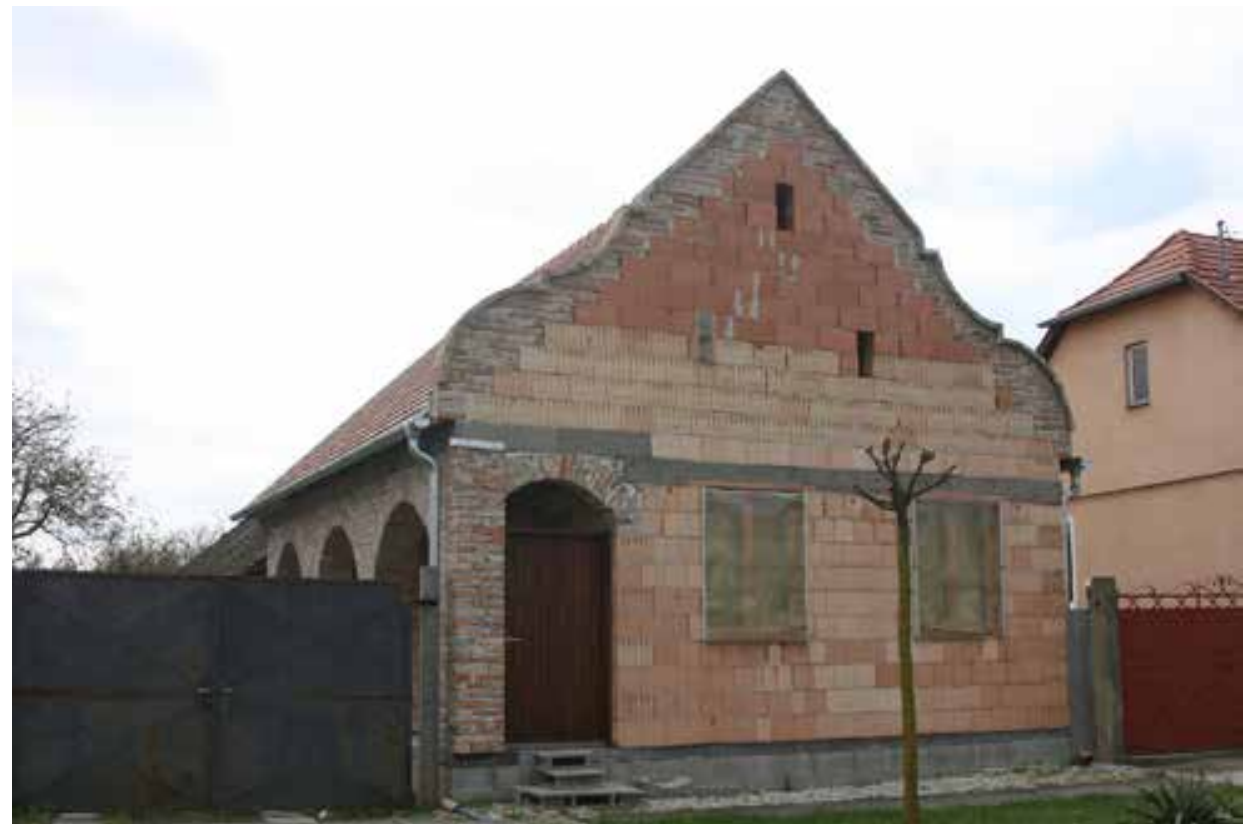

8. ábra. Rossz műszaki állapota miatt elbontott lakóépület rekonstruált oromzata és tömege. Sarród

mentes - egyeztetések után kerülhetett sor. Az épület tömegében részben visszaépült, az utcaképben szinte az eredeti állapotnak megfelelő helyet foglal el (8. ábra).

\section{Historizáló homlokzatok színezése}

Talán az építészettörténet-oktatás egyik hiányossága, hogy a historizáló homlokzatok esetében is nagyon gyakran jelentkezik tervezői oldalról a tagozatok eltérő színüre festésének az igénye. A szétszínezett homlokzatokon többnyire ellentmondás alakul ki: az alaktani szempontból összetartozó elemek kapnak különböző színt. A probléma különösen a század második felében épült, plasztikus díszítésü eklektikus homlokzatok esetében jelentkezik. Hasonló probléma a homlokzati kőelemek natúr színben történő meghagyása. Ezek - különösen abban az esetben, ha a tagozatoknak csupán egy része készült kőből, míg a többi vakolatból van - sokszor a homlokzat optikai széteséséhez vezetnek, és nem is tükrözik híven az építés korának megfelelő állapotot. A hatóság koordináló szerepének köszönhetően több esetben sikerült a felújítás során historizáló homlokzatokat egyszínüre festetni, ilyen módon a müemlék épület látványát az eredeti állapotba visszaállítani és a városképet egy szépen helyreállított épülettel gazdagítani (9-10. ábra). 

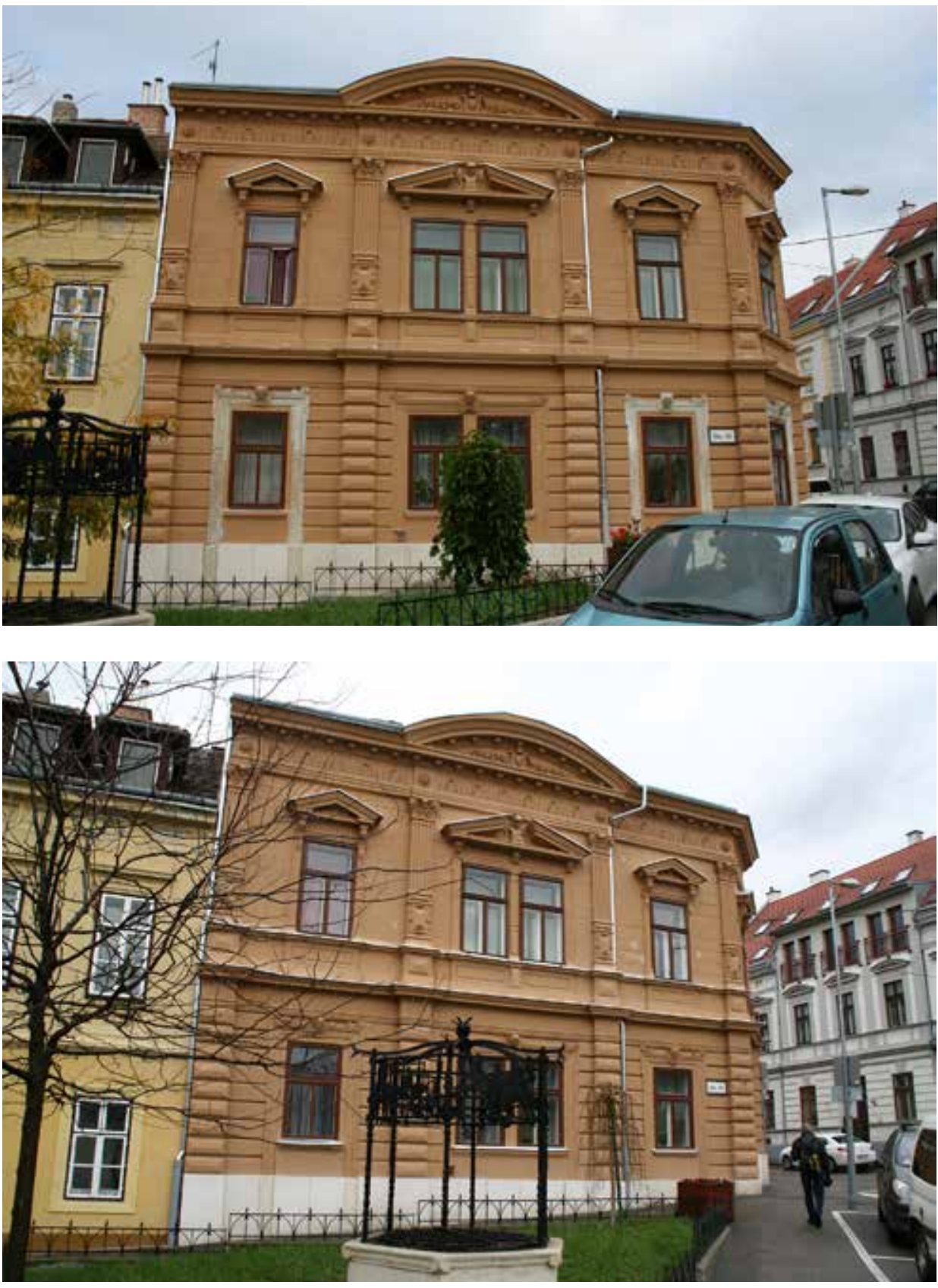

9-10. ábra. A kő színben megtartott kőkeretek zavarják a homlokzat egységét. Az átfestés után helyreállt az architektonikus rend. Sopron, Sas tér 


\section{Sopron, Városháza, előcsarnok padlóburkolat restaurálása}

A 19. század végén épült városháza belsejében mintegy egy évtizeddel korábban került sor a díszterem restaurátori szemléletủ felújítására. Ezt követte az elöcsarnok korszerüsítése. A színes, hatszögü kerámialapokkal burkolt térben a padlóburkolat felbontása és új padló készítése volt az építtetői szándék - melyet elsősorban a padlófütés kiépítése iránti igény generált. A - véleményünk szerint teljesen felesleges - padlófütés elvetésével az eredeti padlóburkolat megőrizhető maradt. A néhány hiányzó lapot egyedileg gyártották le, a sérülteket restaurálták. A tér egy modern hangulatú szélfogóval is gazdagodott (11. ábra).

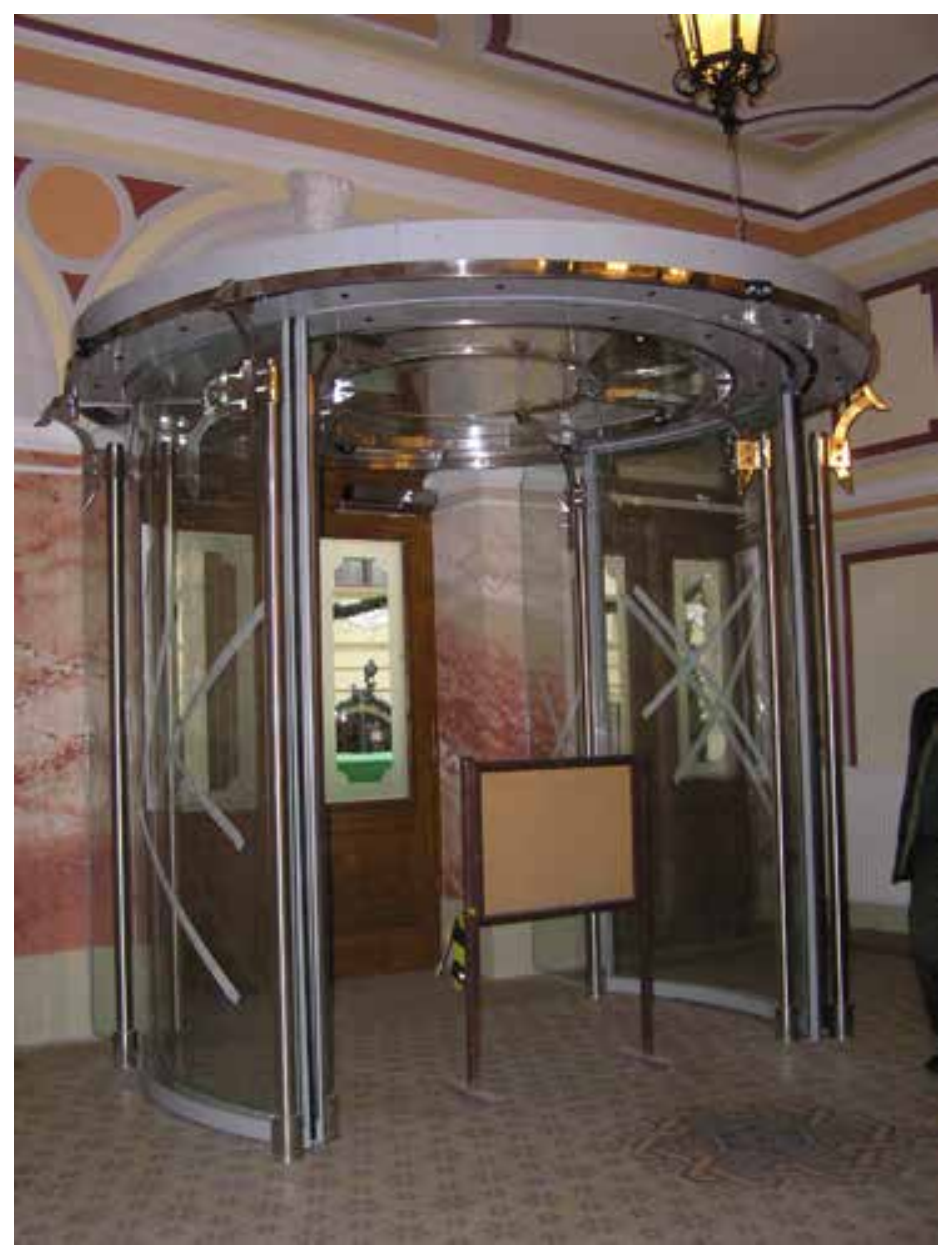

11. ábra. Restaurált padlóburkolat és kortárs hangvételü szélfogó a soproni Városháza épületében 


\section{Fertöszéplak, felújitott ablakok}

A müemlékek megőrzésének leghatékonyabb módja, ha a tulajdonosi szemlélet önmagában az értékek megörzésére irányul. Egy fertőszéplaki, semmiféle védettséget nem élvező lakóház ablakinak mintaszerü helyreállítása készült el ilyen módon, hatósági részvétel nélkül. Az ablaktokok és szárnyak hibáit a sérült részek kivágásával és fabetétezéssel oldották meg. Az ablakok nagy része, a vasalatok, a belső spaletták felújításra kerültek. A külső ablakszárnyakban vékonyított hőszigetelö üvegezést helyeztek el (12. ábra).

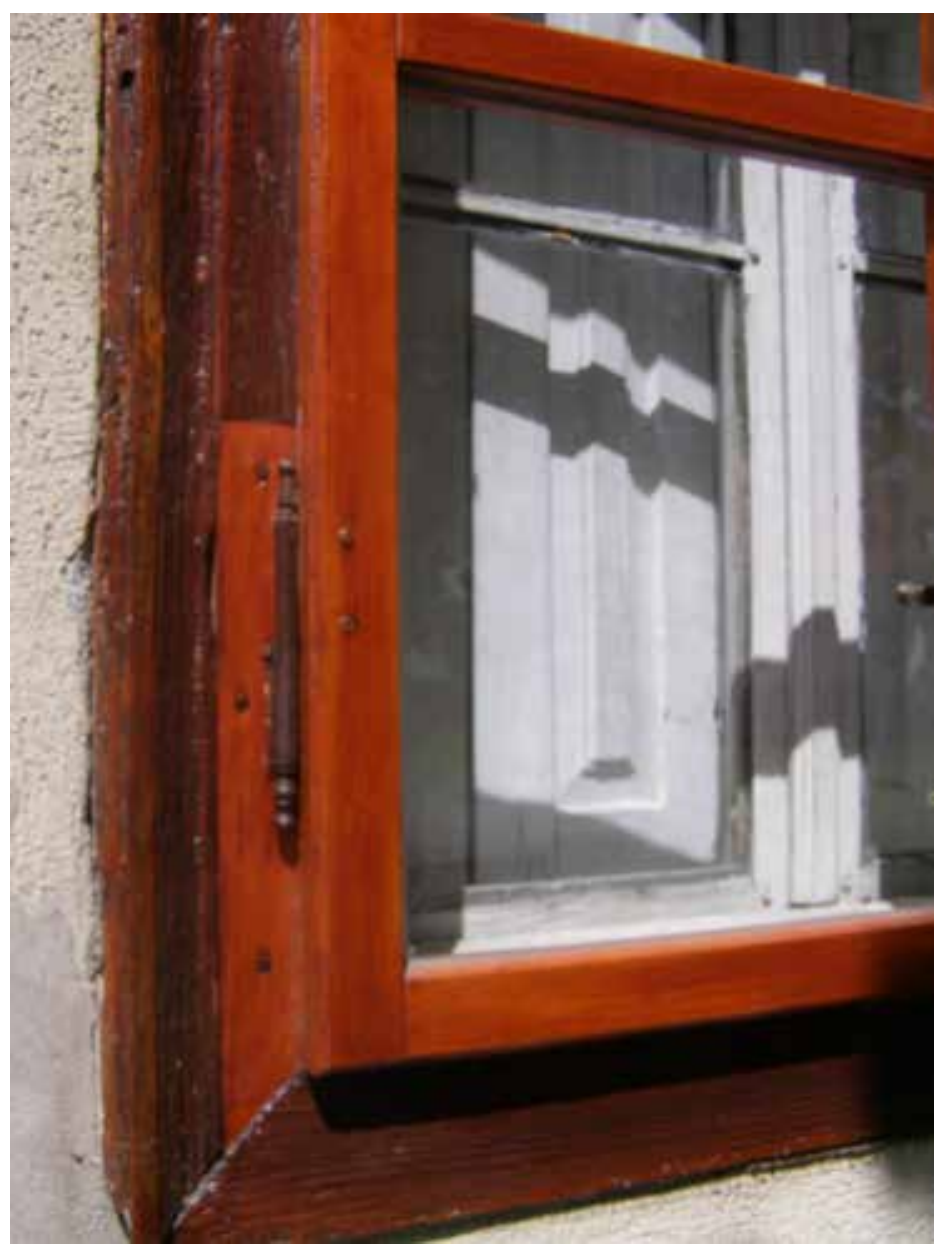

12. ábra. Fertőszéplaki ház ablakának értékőrző felújítása 


\section{Nagylózs, neobarokk templomfestés rekonstrukciója}

Szerencsés eset, amikor a müemlékvédelmi folyamat szereplői, a tulajdonos, a tervező, a kivitelező és a hatóság egységes álláspontot képvisel. A nagylózsi plébániatemplom felújításának aktualitását a templomtér boltozatán megjelenő, rendkívül nagy mértékü repedések adták. A szerkezeti hibák javítása után került sor a templombelső kifestésére. A díszítőfestés alapját a templombelsőről fellelhető - többnyire fekete-fehér - fényképek jelentették, ezek alapján vált lehetővé a 19. század végi 20. század eleji díszítőfestés rekonstrukciója. A fényképek által nem igazolható felületeken az ismert minták stílusában készült a festés (13. ábra).

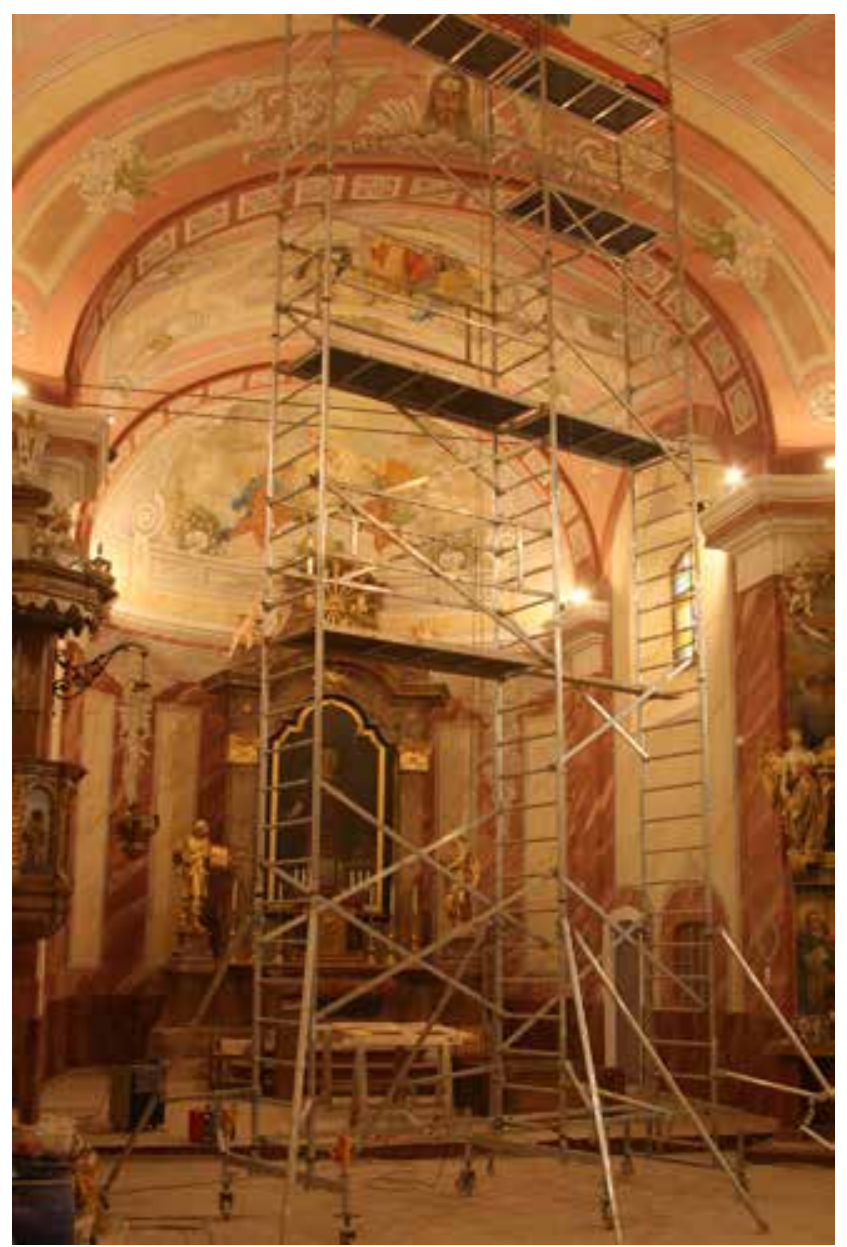

13. ábra. Neobarokk díszítőfestés rekonstrukciója a nagylózsi templomban 


\section{Győr, olajgyári kémény időszakos megmentése}

A 2017. év elején a győri 19. századi ipari építészet egyik utolsó emlékének, a már a 20. század elején megépített - olajgyári kéménynek a bontási szándéka nyomán, a hivatásos müemlékvédelem tehetetlensége (tenni nem akarása?) miatt komoly civil összefogásra került sor az építmény megmentése érdekében. Ennek eredményeképpen a tulajdonos lemondott a robbantásról. A megyei Építész Kamara aláírásgyüjtést kezdeményezett, a Széchenyi Egyetem építészmérnök hallgatói pedig több tanulmánytervet is készítettek a kémény hasznosíthatóságára vonatkozóan.

A rövid távú, haszonorientált beruházói szándék azonban felülírta az értékvédelmi szempontokat: 2018 tavaszán a kéményt elbontották (14. ábra).

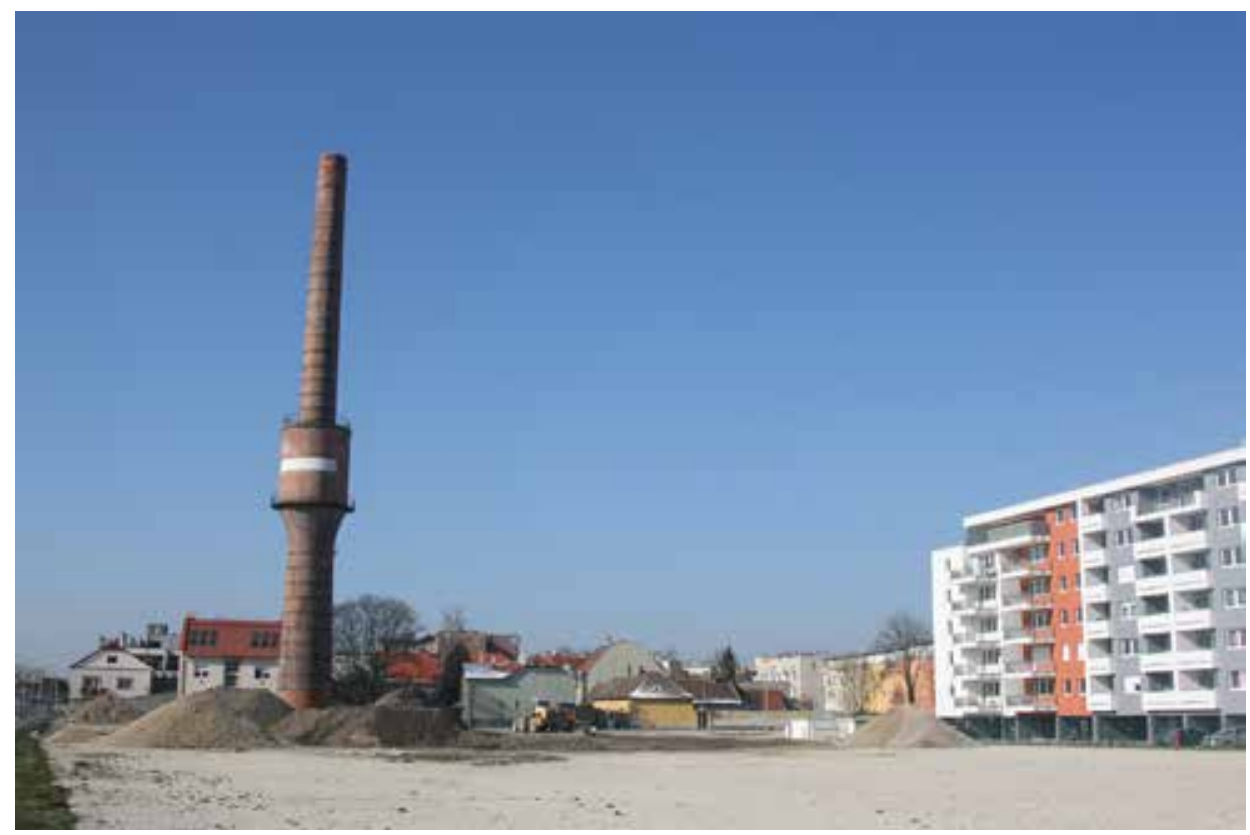

14. ábra. 2018 februárjában még állt a győri ipar hőskorából származó, utolsó gyárkémény

\section{Sopronhorpács, plébániaépület megmentésének lehetöségei}

Az épület jellegzetes példája a lappangó müemléki értékeknek. A sopronhorpácsi román kori templom müemléki környezetében álló, de önmagában védelmet nem élvező épület helyére tervezett új plébániaház kapcsán merült fel, hogy fontos lenne a ház értékeinek számbavétele, illetve müszaki állapotának felmérése. Ennek során kiderült, hogy - néhány ablak befalazásától és két új ablaknyitástól eltekintve - minden részletében megvan a 19. század végi, historizáló épület: $40 \mathrm{~cm}$ széles deszkák- 
ból készült hajópadló, mennyezeti díszítőfestés, domborműves cserépkályha, számos eredeti ablak, ajtó, vasalat, kilincs örzi a ház történeti hangulatát.

$\mathrm{Az}$ értékek tervezői oldalról való fel nem ismerése, a felújítási tervezéssel járó bonyodalmak elkerülésének a szándéka, és ennek következményeként a tervező iránt feltétlen bizalommal levő építtető félretájékoztatása az épület állapotával kapcsolatban oda vezetett, hogy a felújítás, megörzés szándéka helyett kizárólag a bontás és új épület építése szerepel kitüzött célként (15. ábra).

Mint látható, az értékvédelem eredményei szerények, és napjaink folyamatosan újat akaró értékrendjének köszönhetően a hatóságnak minden egyes müemléki értékü épületalkatrészért nagy küzdelmet kell folytatnia. Reméljük azonban, hogy ezek a megmentett értékek hosszú távon is gazdagítják hazánkat, és hozzájárulnak múltunk, történelmünk megismeréséhez, ezáltal a következő generáció identitásának megerősítéséhez.

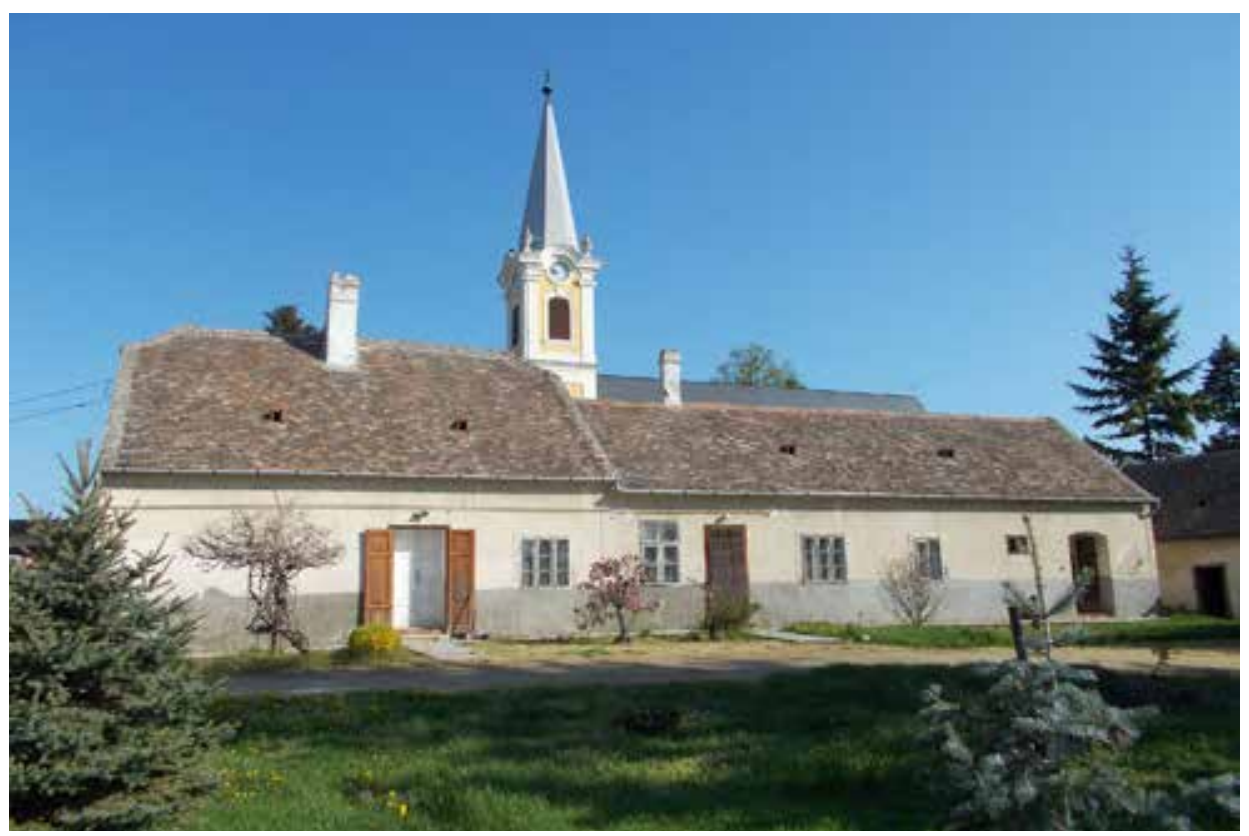

15. ábra. 19. századi, szinte minden alkatrészében eredeti, bontásra ítélt plébániaház a sopronhorpácsi román kori templom mellett 


\title{
PROTECTION OF THE $19^{\text {TH }}$ CENTURY BUILDINGS IN GYÖR-MOSON-SOPRON COUNTY
}

\begin{abstract}
Summary
The ratio of the protected buildings of the $19^{\text {th }}$ century is probably smaller than the ratio of the buildings built in this period within the whole built environment. On the one hand, we protect all the medieval and baroque buildings even if they have only few original elements sometimes only the frame of the building. On the other hand, however, the buildings of the $19^{\text {th }}$ century are original in all the details: walls, roof constructions, portals, doors, windows, skylights, tiles, floors, wrappers, stairs, stays, plasters, wall paintings, tile stoves that show us the richness of the architecture of this age.

The destruction of the monumental values has three different reasons: technical, moral, or bureaucratic obsolescence. In the case of wrecked structures, the renewing is necessary, but it can also lead to the demolition of old details.

This article shows several problems of protection of buildings from the $19^{\text {th }}$ century through different examples.
\end{abstract}

Keywords: historicism, protection of monuments, original parts of the buildings 